\title{
Az egészségértés gyakorlati mérése Magyarországon és nemzetközi összehasonlításban
}

\author{
Koltai Júlia $\mathrm{PhD}^{1,2}$ - Kun Eszter ${ }^{3}$ \\ ${ }^{1}$ Magyar Tudományos Akadémia, Társadalomtudományi Kutatóközpont, Szociológia Intézet, Budapest \\ ${ }^{2}$ Eötvös Loránd Tudományegyetem, Társadalomtudományi Kar, Budapest \\ ${ }^{3}$ Szinapszis Piackutató és Tanácsadó Kft., Debrecen
}

\begin{abstract}
Bevezetés: A tanulmány a gyakorlati egészségértés innovatív mérésének eredményét mutatja be nemzetközi kontextusban. Célkitüzés: Bemutatni a magyar társadalom egészségértését és nemzetközi összehasonlításban elfoglalt helyét. Módszer: A gyakorlati egészségértést az Átlagos Tápérték Teszttel (Newest Vital Sign test) mértük 2015 májusában és júniusában, az Eurobarometer módszertani standardjai szerint, a 16 éves vagy idősebb lakosság 1008 fóvel lekérdezett magyarországi országos reprezentatív mintáján. A minta jól reprezentálja a magyarországi 16 éves vagy idősebb lakosságot nem, életkor, régió, továbbá településméret szerint. Eredmények: Az Átlagos Tápérték Teszt alapján a magyar társadalom tagjai kiemelkedően jó gyakorlati egészségértéssel rendelkeznek. Az eredmény ellentmondásban áll az önbevallással mért gyakorlati egészségértéssel, mivel az kifejezetten alacsony egészségértést mutat. Következtetések: Mivel az önbevalláson alapuló egészségértés alacsony mértékét úgy interpretálhatjuk, hogy a válaszadóknak nincs napi rutinjuk képességeik gyakorlati alkalmazásában, szükség lehet arra, hogy felhívjuk a figyelmüket azon információkra, amelyeket fontos ellenőrizniük élelmiszerek megvásárlásakor, továbbá arra, miként alkalmazzák az ott olvasottakat a gyakorlati döntések meghozatalában. Orv. Hetil., 2016, 157(50), 2002-2006.
\end{abstract}

Kulcsszavak: egészségértés, felmérések és kérdőívek, mentális folyamatok, önértékelés

\section{The practical measurement of health literacy in Hungary and in international comparison}

Introduction: The study presents results of an innovative measurement of practical health literacy in international context. Aim: To show the level of practical health literacy in the Hungarian society and in international comparison. Method: We measured practical health literacy with Newest Vital Sign test on a Hungarian national representative sample, asked from 1008 persons, between May and June, 2015 from population 16 years or older, using methodological standards of Eurobarometer. The sample is representative to the above mentioned population by gender, age, region and settlement-size. Results: Based on Newest Vital Sign test, members of the Hungarian society have good practical health literacy. The accomplishment is inconsistent with self-reported health literacy, since it shows weak results. Conclusions: As low level of self-reported health literacy implies that respondents don't have daily routine in practicing their skills, we could draw people's attention to food-information, that are important and show, how to utilize them.

Keywords: health literacy, surveys and questionnaires, mental processes, self evaluation

Koltai, J., Kun, E. [The practical measurement of health literacy in Hungary and international comparision]. Orv. Hetil., 2016, 157(50), 2002-2006.

(Beérkezett: 2016. június 13.; elfogadva: 2016. szeptember 25.) 
Jelen tanulmány egy olyan kutatásra épül, amely az egészségértést mérte Magyarországon. A kutatás mind tartalmi, mind módszertani szempontból nem előzmény nélküli, mivel egy nemzetközi összehasonlító kutatássorozat magyarországi állomásának tekinthető. A nemzetközi kutatás előkészítését és lebonyolítását egy kifejezetten erre a témára létrejött konzorciumi kutatócsoport végezte, amelynek tagjai az Európai Unió nyolc különböző országából szerveződött. A részt vevő országok a következők voltak: Ausztria, Bulgária, Görögország, Írország, Hollandia, Lengyelország, Spanyolország és Németország (azon belül csak Észak-Rajna-Vesztfália, de a könnyebb átláthatóság érdekében a szöveg további részeiben Németországként hivatkozunk rá).

\section{Célkitüzés}

A tanulmány a nemzetközi kutatássorozat egy olyan elemét mutatja be, amely innovatív módon (az úgynevezett Átlagos Tápérték Teszt segítségével) méri a gyakorlatban alkalmazott egészségértést. Országos reprezentatív mintán azt vizsgálja, hogy egy olyan helyzetben, amelyben a válaszadóknak értelmezniük kell egy tápértéktáblázatot, mely elemek azok, amelyek problémát okozhatnak. A nemzetközi eredményekkel párhuzamba állítva mutatjuk be ezeket az eredményeket a kutatás más részeiből származó különböző egészségértési mérőszámokkal összevetve.

\section{Módszer}

A nemzetközi kutatócsoport (konzorcium) elsőként létrehozta az egészségértés definícióját és elméleti modelljét (konceptualizáció), majd erre építve kvantitatív módszerekhez tervezve, kérdőívkérdésekké fordították az elméleti modellt (operacionalizáció). Az így létrejött kérdőívet végül mind a nyolc országban országos reprezentatív, nagyjából ezerfös mintán kérdezték le, amelynek módszertanát és mintavételét az Eurobarometer nemzetközi kutatássorozat standardjai alapján alakították ki. A kutatások eredményeit többek között egy záró jelentésben publikálták, amely tartalmazza az országok összehasonlító adatait. (A publikált záró jelentés a magyarországi adatokat még nem tartalmazza.) Mivel a cél a nemzetközi kutatással való összehasonlíthatóság volt, így a magyarországi kutatás során mind a kérdőív, mind a módszertani és mintavételi szempontok teljes mértékben megegyeztek a konzorcium által megállapítottakkal [1]. A magyarországi adatfelvétel 2015. május 30. és június 23. között történt a 16 éves vagy idősebb magyarországi lakosság körében, egy 1008 fós országos, reprezentatív mintán, az Eurobarometer nemzetközi kutatássorozat módszertani standardjai mentén. A minta jól reprezentálja a magyarországi 16 éves vagy idősebb lakosságot a válaszadók neme, életkora és a lakóhely régiója, továbbá településmérete szerint.
Az elméleti modellben az egészségértés tizenkét dimenzióját különböztették meg, amelyeket összesen 47 kérdőívkérdéssel mértek, és amelyek két tengely mentén írhatók le. Az egyik tengelyt az egészséggel kapcsolatos témák, úgymint az egészségügy, a prevenció és az egészségfejlesztés teszik ki. A másikat az egészséggel kapcsolatos információk birtoklása, feldolgozása alkotja, úgymint az elérés, a megértés, az értékelés és az alkalmazás [2]. Az elméleti modell alapján létrehozható egy általános egészségértés index, hét alindex, továbbá tizenkét alalindex, amelyek kialakításának módszertana az összehasonlíthatóság érdekében meglehetősen hasonló. (Az indexek létrehozásának módszertanáról lásd részletesebben: $[1,3]$.) Tanulmányunkban az Átlagos Tápérték Teszttel kapcsolatban az alindexek közül az Összesített egészségértés indexen túl az egészségügyi rendszerrel kapcsolatos tudatosságot, a prevenciót és az egészségfejlesztést mérő alindexekkel foglalkozunk részletesebben.

Az egészségértés gyakorlati mérésére egy olyan, speciális módszert használtak a konzorcium kutatói, amelynek alapja, hogy a kérdezettnek megmutatnak egy képzeletbeli fagylaltcsomagolás hátoldalán található címkét, amely a termék tápértékére vonatkozóan tartalmaz információkat. (A módszerről részletesebben a http:// www.pfizer.com/files/health/nvs_flipbook_english_final.pdf ad tájékoztatást.) Miután a válaszadó tanulmányozta a címkét, különböző kérdéseket tesznek fel a tápértéktáblázattal kapcsolatban. A kérdésre adott válaszokhoz mind az értékek értelmezésének ismeretére, mind pedig numerikus képességekre szükség van. A teszt segítségével azt mérik, hogy a kérdezett mennyire képes megérteni és alkalmazni a címkén található információkat. A teszt során összesen hat kérdést tesznek fel, amelyekre a címkén található információk segítségével kell válaszolni. Az eredmény egy olyan szám, amely megmutatja, hogy a hat kérdésből hányra válaszolt helyesen a kérdezett. Az eredmények alapján a válaszadók három csoportba sorolhatók: nagy valószínúséggel korlátozott egészségértésúek (0-1 pont); valószínúleg korlátozott egészségértésüek (2-3 pont); nagy valószínűséggel megfelelő egészségértésűek (4-6 pont). Az alábbiakban e teszt eredményeit elemezzük és vetjük össze a nemzetközi kutatásban részt vevő nyolc ország eredményeivel [1].

\section{Eredmények}

Az Átlagos Tápérték Teszt eredményeit a 0-tól 6-ig terjedő skála leíró statisztikái mellett az előbbiekben leírt három kategória mentén mutatjuk be Magyarországra vonatkozóan, majd ezeket az adatokat összehasonlítjuk a nemzetközi kutatócsoport nyolc országának eredményeivel. Az eredményeket az 1. táblázat szemlélteti.

A magyar kutatás alapján a társadalom valamivel több mint tizede tartozik a nagy valószínûséggel korlátozott kategóriába, és egészségértési szempontból minden ötödik magyar valószínúleg korlátozott készségekkel ren- 
1. táblázat |Az átlagostápérték-teszt eredményei (sorszázalék, átlag és szórás 0-6 skálán)

\begin{tabular}{|c|c|c|c|c|c|}
\hline & $\begin{array}{l}\text { Nagy } \\
\text { valószínú- } \\
\text { séggel } \\
\text { korlátozott } \\
\text { gyakorlati } \\
\text { egészség- } \\
\text { értés }\end{array}$ & $\begin{array}{l}\text { Valószínúleg } \\
\text { korlátozott } \\
\text { gyakorlati } \\
\text { egészség- } \\
\text { értés }\end{array}$ & $\begin{array}{l}\text { Nagy } \\
\text { valószínü- } \\
\text { séggel } \\
\text { megfelelő } \\
\text { gyakorlati } \\
\text { egészség- } \\
\text { értés }\end{array}$ & Átlag & Szórás \\
\hline $\begin{array}{l}\text { Magyarország } \\
\text { (HU) }\end{array}$ & 12 & 20 & 69 & 4,2 & 1,9 \\
\hline Ausztria (AT) & 13 & 22 & 66 & 4,1 & 1,9 \\
\hline Bulgária (BG) & 29 & 25 & 46 & 3,1 & 2,1 \\
\hline $\begin{array}{l}\text { Németország } \\
\text { (GER) }\end{array}$ & 16 & 22 & 62 & 3,9 & 2,0 \\
\hline $\begin{array}{l}\text { Görögország } \\
\text { (GRE) }\end{array}$ & 18 & 28 & 54 & 3,6 & 2,0 \\
\hline $\begin{array}{l}\text { Spanyolország } \\
\text { (ES) }\end{array}$ & 34 & 29 & 37 & 2,6 & 2,0 \\
\hline Írország (IR) & 20 & 23 & 58 & 3,6 & 2,1 \\
\hline $\begin{array}{l}\text { Hollandia } \\
\text { (NL) }\end{array}$ & 9 & 15 & 76 & 4,5 & 1,8 \\
\hline $\begin{array}{l}\text { Lengyelország } \\
(\mathrm{PL})\end{array}$ & 32 & 26 & 42 & 2,9 & 2,1 \\
\hline EU-minta & 21 & 23 & 55 & 3,5 & 2,1 \\
\hline
\end{tabular}

HU: $\mathrm{N}=1008 ;$ AT: $\mathrm{N}=10139 ; \mathrm{BG}: \mathrm{N}=1002 ;$ GER: $\mathrm{N}=1057$; GRE: $\mathrm{N}=1000$; ES: $\mathrm{N}=1000$; IR: $\mathrm{N}=1005$; $\mathrm{NL}: \mathrm{N}=1023$; PL: $\mathrm{N}=1000 ;$ EU-minta: $\mathrm{N}=8100$.

Konzorciumi országok eredményeinek forrása: HLS-EU Consortium 2012: 28

2. táblázat | A következő kérdésre adott válaszok eloszlása és átlaga: „Kérem adja meg ezen a skálán, hogy Ön szerint mennyire könnyü, illetve nehéz megérteni az élelmiszerek csomagolásán olvasható informá ciókat"

\begin{tabular}{llllll}
\hline $\begin{array}{l}\text { Nagyon } \\
\text { nehéz }\end{array}$ & $\begin{array}{l}\text { Inkább } \\
\text { nehéz }\end{array}$ & $\begin{array}{l}\text { Inkább } \\
\text { könnyú }\end{array}$ & $\begin{array}{l}\text { Nagyon } \\
\text { könnyú }\end{array}$ & Nem tudja Átlag \\
\hline $10 \%$ & $32 \%$ & $42 \%$ & $16 \%$ & $1 \%$ & 2,7 \\
\hline
\end{tabular}

delkezik. Érdekes eredmény, hogy tízből nagyjából hét ember nagy valószínúséggel megfelelő egészségértéssel bír, ami kiemelkedően jó eredménynek tekinthetố a gyakorlati egészségértés terén.

Azt láthatjuk, hogy a kutatássorozat nyolc uniós országának összesített eredményeihez képest a magyar eredmények kiugróan jók (4,2-es magyarországi átlag, a többi ország összesített, 3,5-es átlagához képest). Az összesen vizsgált kilenc ország többségének lakossága meglehetősen jó gyakorlati egészségértéssel jellemezhető, mivel a 0-tól 6-ig tartó skálán 3,6 és 4,2 közötti átlagokat mutatnak. Kiugróan magas (4,5-es) Hollandia átlaga, amelyet úgy értelmezhetünk, hogy a hollandok körében kiemelkedően jó a gyakorlati egészségértés.
Ugyanez az érték azonban kifejezetten alacsony (2,6 és 3,1 közötti) Bulgária, Spanyolország és Lengyelország esetében, ezeknek az országoknak a lakosai tehát a teszt alapján inkább korlátozott gyakorlati egészségértéssel jellemezhetők.

Különösen érdekes ez az eredmény abból a szempontból, hogy az Összesített egészségértés indexet méró kérdőívkérdések eredményei közül Magyarországon annál láthatjuk az egyik legalacsonyabb átlagot, amely arra vonatkozik, hogy mennyire nehéz a kérdezettnek megértenie az élelmiszerek csomagolásán olvasható információkat: a változó átlaga a közepesnél (a skála elméleti közepénél - 2,5) éppen hogy magasabb volt (2,7-es), a többi kérdésre adott válasz átlagához képest pedig kifejezetten alacsonynak mondható (a legalsó 15\%-ban helyezkedik el). A változó eloszlását és átlagát a 2. táblázat mutatja. Az alacsony átlag ebben az esetben arra utal, hogy a kérdezetteknek egy-egy ilyen címke értelmezése a mindennapokban valamilyen mértékben nehézséget okoz.

Annak érdekében, hogy megvizsgáljuk, hogy a gyakorlati egészségértés mennyire függ össze az elméleti egészségértéssel, megvizsgáltuk az összesített egészségértés, továbbá a már említett három alindex kapcsolatát az Átlagos Tápérték Tesztből kapott eredményeinkkel. Az összevetés a 3. táblázatban látható.

A gyakorlati egészségértést mérő Átlagos Tápérték Teszt az egészségértés elméleti mérőeszközei közül legerősebben az Egészségfejlesztési alindexszel függ össze, hasonló erősséggel, mint az Összesített egészségértés indexszel. Fontos azonban felhívni a figyelmet arra, hogy ezek a korrelációk sem túl erősek, mivel értékük 0,23 és 0,21 (vö. a korrelációk elméleti maximuma 1). A gyakorlati egészségértés az egészségügyi rendszerrel kapcsolatos tudatossággal és a prevencióval valamivel gyengébb mértékben függ össze, ezekben az esetekben a korreláció nagysága 0,18 és 0,14 . Azt mondhatjuk tehát, hogy az elméleti és gyakorlati egészségértés - legalábbis ilyen módon mérve - nem függnek össze erôsen egymással.

$\mathrm{Az}$ Összesített egészségértés indexnek és három alindexének összefüggése az Átlagos Tápérték Teszt eredményeivel (a gyakorlati egészségértéssel) minden esetben azt mutatta, hogy a legerősebb összefüggések Bulgáriában és Lengyelországban vannak, a leggyengébbek pedig Hollandiában (ahol két esetben az összefüggés nem is volt szignifikáns) és Németországban. Az elméleti és a gyakorlati egészségértés tehát előbbi országokban koherensebb képet mutat, utóbbiakban pedig szinte teljesen elválik egymástól.

\section{Következtetések}

Az eredményeket úgy interpretálhatjuk, hogy Magyarország a gyakorlati egészségértés terén mind objektív, mind a nemzetközi kutatásban szereplő nyolc európai országhoz képest meglehetősen jó pozícióban van. A magyarok több mint kétharmada a nagy valószínúség- 
3. táblázat |Az átlagostápérték-teszt kapcsolata az egészségértés-indexekkel (Spearman-féle Rho-korrelációk)

\begin{tabular}{|c|c|c|c|c|c|c|c|c|c|c|c|}
\hline & & $\mathrm{HU}$ & AT & BG & GER & GRE & ES & IR & NL & PL & EU8 \\
\hline \multirow{2}{*}{$\begin{array}{l}\text { Átlagos Tápérték Teszt vs. } \\
\text { Összesített egészségértés index }\end{array}$} & $\mathrm{r}$ & 0,21 & 0,2 & 0,34 & 0,13 & 0,29 & 0,23 & 0,24 & 0,07 & 0,33 & 0,25 \\
\hline & $\mathrm{N}$ & 955 & 1007 & 1005 & 1161 & 1043 & 1009 & 972 & 992 & 1044 & 8233 \\
\hline \multirow{2}{*}{$\begin{array}{l}\text { Átlagos Tápérték Teszt vs. } \\
\text { Egészségügyi rendszerrel } \\
\text { kapcsolatos tudatosság alindex }\end{array}$} & $\mathrm{r}$ & 0,18 & 0,18 & 0,35 & 0,15 & 0,28 & 0,2 & 0,2 & 0,11 & 0,31 & 0,24 \\
\hline & $\mathrm{N}$ & 961 & 1024 & 1039 & 1158 & 1043 & 1016 & 984 & 992 & 1080 & 8336 \\
\hline \multirow{2}{*}{$\begin{array}{l}\text { Átlagos Tápérték Teszt vs. } \\
\text { Prevenció alindex }\end{array}$} & $r$ & 0,14 & 0,17 & 0,34 & 0,08 & 0,23 & 0,17 & 0,19 & 0,05 & 0,32 & 0,22 \\
\hline & $\mathrm{N}$ & 964 & 1009 & 1005 & 1164 & 1039 & 1020 & 961 & 994 & 1043 & 8235 \\
\hline \multirow{2}{*}{$\begin{array}{l}\text { Átlagos Tápérték Teszt vs. } \\
\text { Egészségfejlesztési alindex }\end{array}$} & $r$ & 0,23 & 0,17 & 0,30 & 0,15 & 0,31 & 0,22 & 0,24 & 0,05 & 0,32 & 0,23 \\
\hline & $\mathrm{N}$ & 956 & 981 & 979 & 1120 & 1039 & 986 & 973 & 979 & 1008 & 8065 \\
\hline
\end{tabular}

AT = Ausztria BG = Bulgária; ES = Spanyolország; GER = Németország; GRE = Görögország; HU = Magyarország; IR = Írország; NL = Hollandia; PL = Lengyelország.

A nem szignifikáns eredményeket dölt betüvel jelöltük. Minden más korreláció szignifikáns 0,05-os szinten.

Konzorciumi országok eredményeinek forrása: HLS-EU Consortium 2012: 29.

gel megfelelő gyakorlati egészségértéssel rendelkezők kategóriájába esik, és csak kicsivel több, mint tizedük tartozik a nagy valószínüséggel korlátozott kategóriába. A kutatásban részt vevő kilenc ország közül ennél csak Hollandiában tapasztaltunk jobb eredményeket. A holland és a magyar adatokat összehasonlítva azt észleltük, hogy Magyarországon a gyakorlati egészségértés erősebben függ össze a szintén ebben a kutatásban mért elméleti (önbevalláson alapuló) egészségértéssel - akár az összesített mérőszámot vesszük figyelembe, akár az egészségügyi rendszerrel kapcsolatos tudatosság, prevenció vagy egészségfejlesztés alindexével mérjük azt. A nemzetközi összehasonlítás azért is kiemelkedően fontos, mert szemben a gyakorlati egészségértéssel, az elméleti egészségértésnél a többi országgal összehasonlítva nem különösebben kiemelkedőek az eredmények. Magyarországon az elméleti (önbevalláson alapuló) egészségértés ugyan tendenciájában hasonlít a más európai országokban jelen lévő trendekben tapasztalhatókkal, azonban a mértéke valamelyest alacsonyabb annál. Ha az országokat egyenként vesszük, azt mondhatjuk, hogy a vizsgált országok közül Magyarországnál csak Bulgária van rosszabb helyzetben az elméleti egészségértés szempontjából. A magyarországi eredmények a legtöbb esetben majdnem teljesen megegyeztek az Ausztriában mértekkel, tehát Magyarországon az egészségértés helyzete jelenleg az ausztriai helyzethez hasonlít a legjobban.

$\mathrm{Az}$ eredményeknél többször jelzett ellentmondást az elméleti és a gyakorlati egészségértés között egy módszertani és egy szakmai hipotézissel oldhatjuk fel. A módszertani hipotézis lényege, hogy az Átlagos Tápérték Teszthez tartozó kérdőíven a kérdezőbiztosok lát- hatták, hogy melyek a kérdésekre adandó helyes válaszok, így akár önkéntelenül is, de segíthették a kérdezetteket a válaszadásban. Érdemes lenne megcsinálni ugyanezt a tesztet oly módon, hogy a kérdezőbiztosok nem láthatják a helyes válaszokat, hanem csak rögzíteniük kell a kérdőíven a válaszadó által mondottakat, és azokat csupán a kérdőívek feldolgozásakor sorolnák be a kutatók helyes és helytelen válaszokká. Ha hipotézisünk helyesnek bizonyulna, azt láthatnánk egy ilyen helyzetben, hogy jelen kutatáshoz képest csökkenne a megfelelő gyakorlati egészségértéssel rendelkezők aránya.

A szakmai hipotézis pedig arra reflektál, hogy az eredmények alapján a Magyarországon élők sokkal kevésbé bíznak saját képességeikben, mert alulbecsülik magukat a tápértékeket tartalmazó címkék megértésével kapcsolatban. Lehetséges, hogy mivel többségüknek a hétköznapokban nincs szükségük ezen információk részletesebb feldolgozására, így a rutin hiánya miatt vélik úgy, nem képesek ilyesmire, vagy numerikus készségeiket kevéssé képesek egy pontosan megfogalmazott, szinte iskolás feladat keretein kívül a való életben alkalmazni. Amikor azonban konkrét feladatként jelenik meg az információk feldolgozása, az egzakt kérdéseket - ha szükséges - képesek megválaszolni. Amennyiben az általunk felvázolt szakmai hipotézis igaz, elsősorban arra van szükség, hogy felhívjuk az emberek figyelmét, hogy mik azok az információk, amelyekre fontos figyelniük az élelmiszerek megvásárlásakor (hiszen azok megértése már kevesebb problémába ütközik), és miként alkalmazzák az ott olvasottakat a fogyasztást befolyásoló gyakorlati döntések meghozatalakor. 
Anyagi támogatás: A kutatás magyarországi megvalósulását anyagilag támogatta az Innovatív Gyógyszergyártók Egyesülete. A szerzők a cikk megírásáért anyagi támogatásban nem részesültek.

Szerzői munkamegosztás: K. E.: A kutatási koncepció kidolgozása, a nemzetközi kutatócsoporttal való kapcsolattartás, az eredmények interpretációja. K. J.: A statisztikai elemzések elkészítése, az eredmények interpretációja. A cikk végleges változatát mindkét szerző elolvasta és jóváhagyta.

Érdekeltségek: Az Innovatív Gyógyszergyártók Egyesülete anyagilag támogatta a szerzők megjelenését a 2015ben rendezett, „The 3rd European Health Literacy Conference"-en, ahol a magyarországi eredményekből készült előzetes elemzés bemutatásra került.

\section{Irodalom}

[1] HLS-EU Consortium (2012): Comparative report of health literacy in eight EU member states. The European Health Literacy Survey HLS-EU (first revised and extended version, date july 5th, 2013), online publication: http://www.health-literacy.eu

[2] Sorensen, K., Van den Broucke, S., Fullam, J., et al.: Health literacy and public health: A systematic review and integration of definitions and models. BMC Public Health, 2012, 12, 80.

[3] Pelikan, J. M., Röthlin, F., Ganabl, K., et al.: Measuring comprehensive health literacy in general populations - the HLS-EU instruments. The Second International Conference of Health Literacy and Health Promotion, October 6-8, 2014, Taipei/ Taiwan.

(Kun Eszter, Budapest, Erzsébet királyné útja 112., 1142 e-mail: kun.eszter@szinopszis.hu)

\section{XVIII. kerületben EGYNAPOS SEBÉSZET kiadó}

A közel negyed évszázada sikeresen müködő ORMOS Intézet újonnan kialakított, mintegy $300 \mathrm{~m}^{2}$-es egynapos sebészeti részlege részben vagy teljes egészében (nagyon kedvező feltételekkel) bérbe vehető, akár egy óra időtartamra is.

A rendelő ÁNTSZ engedéllyel rendelkezik. Tömegközlekedéssel és autóval is könnyen megközelíthető, ingyenes parkolási lehetőség az utcán megoldott.
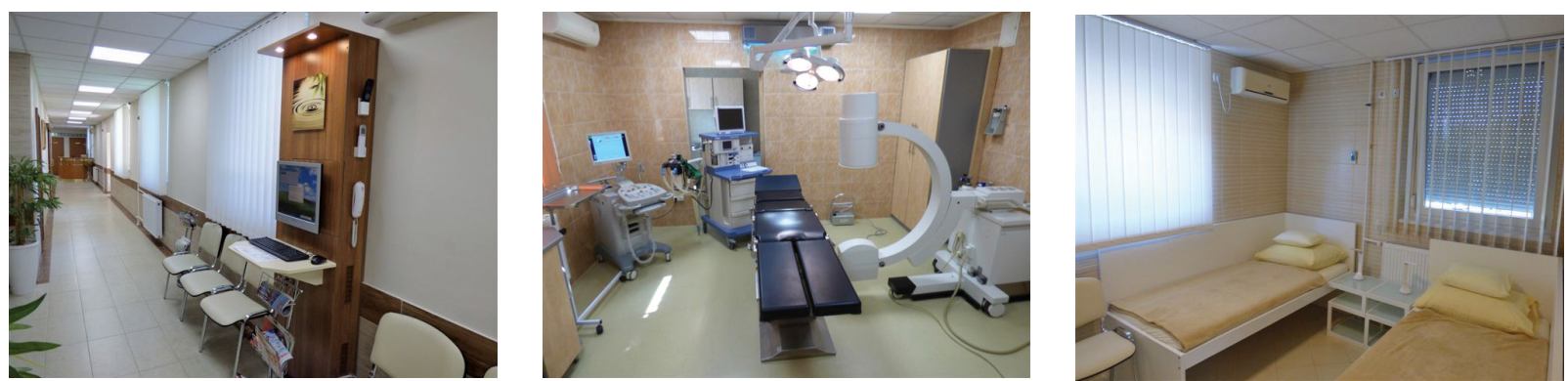

Érdeklődés esetén bővebb információért kérem, forduljon Parádi Ildikó ügyvezető igazgatóhoz.

Tel.: +36 205551680 